\title{
Techno-economic evaluation of strategies for addressing energy and environmental challenges of industrial boilers in China
}

\author{
Bo Shen ${ }^{1, *}$, Yafeng Han $^{2}$, Lynn Price ${ }^{1}$, Hongyou Lu ${ }^{1}$, Manzhi Liu ${ }^{3}$ \\ ${ }^{1}$ Energy Analysis \& Environmental Impacts Division, Energy Technologies Area, Lawrence Berkeley National \\ Laboratory, One Cyclotron Road, MS 90R2002, Berkeley, CA 94720, U.S.A. \\ ${ }^{2}$ Henan University of Economics and Law, 1 Jinshui E Rd, Jinshui, Zhengzhou, Henan, China \\ ${ }^{3}$ School of Management, China University of Mining and Technology, Xuzhou Jiangsu 221116, China \\ * Correspondence: E-mail address: boshen@lbl.gov; Tel.: +1 5104958880.
}

\begin{abstract}
Tackling coal-burning industrial boilers is one of the key solutions to meeting the climate change and solving the environmental problem in China. Assessing the economics of various options to address coal-fired boilers is essential to identify cost-effective solutions. This paper discusses our work in conducting a comprehensive techno-economic analysis to evaluate various strategies for improving efficiency and maximize fuel-switching of industrial boilers. The analysis focused on three options: (1) fuel switching to replace coal with alternative fuels for small size of boilers; (2) retrofitting boilers through a series of efficiency improvement measures; (3) developing community-scale, distributed systems to replace otherwise scattered boilers operated by individual industrial facilities. Key barriers that prevent these solutions from being fully captured are discussed and policy recommendations to tackle these barriers are provided.
\end{abstract}

Keywords: Energy efficiency; fuel switching; distributed CHP; industrial coal-fired boilers; natural gas; China

\section{Introduction}

Boilers are common but critical pieces of equipment in energy conversion systems and are widely used in power plants, manufacturing facilities, as well as buildings. Compared to other end-use boilers, industrial boilers are predominant, adopted across manufacturing sectors and systems, and operated in a dispersed manner in China. As of the end of 2012, there were 467,000 coal-fired industrial boilers in China, with a total capacity of 1.78 million steam tons. These boilers consume about 700 million tons of coal annually, accounting for $18 \%$ of the nation ${ }^{\text {ee }}$ s total coal consumption [1]. According to the Energy Research Institute [2], coal represents about 80\% of the total energy input to industrial boilers and oil contributes another $15 \%$. The use of natural gas and biomass in industrial boilers is very limited in China. China ses industrial boilers are 
characterized as small in size with average capacity of about 3.8 tons/hour [2]. Raw coal is the main fuel consumed by industrial boilers in China. Compared with coal used for large power plants, the quality of coal used in industrial boilers is poor with high ash and sulfur content. Very often, boiler operators choose to use raw coal, instead of washed coal which is cleaner but has a higher cost [2]. Overall energy efficiency of coal-fired industrial boilers in China is relatively low, about $15 \%$ lower than the international advanced level [3].

Together these boiler systems in China are one of the major sources contributing to the climate change, producing approximately 1.3 gigatons $(\mathrm{Gt})$ of carbon dioxide $\left(\mathrm{CO}_{2}\right)$ annually [4]. These boiler systems are also responsible for $33 \%$ and $27 \%$ of total soot and sulfur dioxide $\left(\mathrm{SO}_{2}\right)$ emissions in China, respectively, making a substantial contribution to the nation "es local environmental degradation [1]. In recent years, there have been extensive severe fog and haze weather across China, which is closely related to the regional high intensity and low-altitude emissions from operations of industrial systems including coal-fired boilers [1].

The Chinese government - at both the national and local level - is taking aggressive actions to mitigate the significant greenhouse gas emissions and air pollution related to the country $\mathrm{s}$ extensive operation of industrial coal-fired boilers. Over the last 4 years, a series of policy related to industrial boilers including a national Boiler Action Plan has been issued by various Chinese Ministries for reducing energy use and controlling pollution of coal-fired industrial boilers [1]. Eliminating or retrofitting inefficient coal-fired boilers is one of the key measures. The government policies also encourage fuel switching from coal to alternative fuels and development of natural gas based distributed energy and combined heat and power.

Taking effective measures requires assessing the cost-effectiveness of possible options. A comprehensive study was conducted under the U.S.-China Climate Change Working Group to evaluate the economics of various strategies for improving efficiency and maximize fuelswitching of industrial boilers in China. This paper discusses the study. The remainder of this paper is organized as follows. The options that are assessed in the study and methodology applied in assessing these options are presented in next section and the discussion of evaluation results is followed. The paper then discusses some of the key barriers that prevent these solutions from being fully captured. The paper concludes with policy recommendations for China to remove the barriers identified in the study and to capture cost-effective opportunities.

\section{Methodology}

\section{Alternative solutions to existing coal-fired boilers}

China s national and local government action plans mandate that coal-fired boilers with a steam production capacity smaller than 20 tonnes per hour $(\mathrm{t} / \mathrm{h})$ need to be eliminated while coalfired boilers with a steam production capacity equal or larger than $20 \mathrm{t} / \mathrm{h}$ be retrofitted to meet the government requirements for efficiency improvement and pollution reduction. Taking into account these requirements, this study focused on three options as alternatives to existing coalfired industrial boilers: (1) fuel switching to replace coal with alternative fuels for small size of boilers; (2) retrofitting existing boilers through a series of efficiency improvement measures; (3) developing community-scale energy service centers to replace scattered boilers operated by individual industrial facilities. Assessing the first option focused on comparing the economic feasibility of replacing a small-sized coal-fired boiler (10 t/h capacity under this option) with a comparable boiler that uses other resources including natural gas, heavy oil, biomass, and electricity. The analysis of the second option evaluated nine types of energy-saving retrofit measures that are either listed in the "National Key Energy-Saving Technology Promotion 
Catalogues" published by China 's National Development of Reform Commission (NDRC) or based on the recommendations by the experts in the field $[5,6]$.

The third option took a new approach that is different from traditional solution. In this option, a distributed energy service center such as a community-scale boiler system is applied to meet the aggregated loads of heat and steam of multiple neighboring companies (in an industrial park setting, for example). In the industrial sector, due to the differentiated demand for heat and steam load across industrial users, it is difficult to rely on a large-scale, centralized service. Establishing distributed energy centers have several advantages. First, such a system can not only meet differentiated demands of industrial users but also achieve higher resource utilization efficiency that cannot be achieved by scattered boilers of small sizes. Second, a distributed energy center can use more efficient technologies (such as combined heat and power, CHP) that are not always cost-effective if used at a very small scales. Third, replacing a number of dispersed boilers with an integrated community-scale system could significantly reduce the cost of controlling and monitoring emissions from scattered pollution sources.

\section{Literature review}

We conducted a literature review to examine studies related to assessing industrial boiler energy efficiency and fuel switching opportunities. Song [7], Mao et al. [8], and Coria [9] discussed the implications of replacing coal with natural gas as a cleaner combustion fuel and concluded that use of natural gas could achieve energy savings when compared to using coal. Fang et al [10], Aunan et al. [11], and Mao et al [8] focused on cost-benefit analyses of natural gas substitution with results showing that substituting natural gas for coal could make economic sense in large cities with dense populations and intensive economic activity. Sims et al. [12], Demirbas [13], Zhang et al [14], Saidur et al. [15], Li et al. [16] focused on switching from coal to biomass in boilers and covered many related aspects including composition of biomass, comparison between biomass and other fuels, combustion of biomass, co-firing of biomass and coal, transportation of biomass, densification of biomass, economic and social impacts of biomass, and future trend of using biomass energy. Laursen and Grace [17], Sims et al [12], Li et al. [16], and Li et al. [18] examined environmental impacts of using biomass in industrial boilers, such as land and water resources, soil erosion, loss of biodiversity, and deforestation were discussed in the literature along with the assessment of technical issues such as fouling, marketing, low heating value, storage and collections, and handling. Yang and Dixon [19] discussed case studies on evaluating World Bank programs in improving energy efficiency for boiler steam systems in China and Vietnam. The United Nations Industrial Development Organization looked at the system-wide efficiency opportunities in the steam system and developed a modelling framework to quantify the energy saving potential and associated costs of implementation of an array of steam system optimization measures in China [6]. Fang et al. [10], Aunan et al. [11], Mao et al. [8], and He et al. [20] conducted studies to estimate the environmental and health impacts of improving energy efficiency of industrial boilers and quantify the co-benefits of reducing carbon emissions and improving air quality in addressing industrial boilers in China.

Studies are also conducted to assess particular systems in which boilers are an important component. Xiong et al. [21] simulated three different heat strategies for China, including the current heat strategy, an individual heat strategy, and a district heating strategy. Their study pointed out that boilers would continue to play an important role in these strategies. It also pointed out that it is much more technically and economically optimal to use industrial waste heat for district heating. Their research discussed the potential of an expanded district heating 
network in tackling China se energy and climate challenges and showed that improving boiler efficiency plays a key role in metalizing the new district heating strategy. Liu et al. [22] pointed it out that combined heat and power plants, which include industrial boilers as key components, would play an important role in enhancing the grid stability when integrating renewable energy, such as wind and solar.

The literature review reveals that there is a general lack of studies that focus on identifying comprehensive solutions targeting small-scale industrial coal-fired boilers in China. This underscores the need to develop appropriate methodology to assess the cost-effectiveness of various alternatives to eliminating small coal-fired industrial boilers in China.

\section{Cost comparison of using different fuels to operate different boiler systems}

In assessing fuel switching opportunities as well as the option of replacing scattered boilers with a community-scale boiler system, we used the method of equivalent annual cost $(\mathrm{EAC})^{1}$ to compare the annualized costs of using different boiler fuels to operate different boiler systems. Annualized costs include annualized capital costs and annual operational costs.

Annualized capital cost $(\mathrm{F})$ is calculated as:

$$
F=\text { Investment } \operatorname{Cos} t \times \frac{d}{1-(1+d)^{-n}}
$$

where:

$\mathrm{d}$ : discount rate

$\mathrm{n}$ : lifetime of boiler equipment

Operational cost $(\mathrm{O})$ is calculated as:

$$
\begin{gathered}
O=\text { fuel cost }+ \text { water cost }+ \text { electricity cost }+ \text { labor cost }+ \text { maintenance cost } \\
+ \text { pollution control cost }
\end{gathered}
$$

\section{Energy-saving cost curve of energy efficiency measures}

Energy-saving cost curve is constructed to determine the economic and technical potentials of various retrofit measures for boiler efficiency improvement. The net cost ${ }^{2}$ per unit of energy saved (represented by y axis) and the energy saving potential (x axis) are calculated to create the energy-saving cost curve. The area below the $\mathrm{x}$ axis (represented in a grid chart) indicates that the cost-savings from the reduced energy use are greater than the investment costs over the lifetime of the technology and thus measures are cost-effective while the area above the $\mathrm{x}$ axis indicates cost-savings are smaller than the investment cost and thus measures are not costeffective.

The cost of saved energy, or CSE, is calculated as:

$$
C S E=\frac{F+O-p \times \Delta E-S}{\Delta E}
$$

\footnotetext{
${ }^{1}$ Equivalent annual cost (EAC) is the cost per year of owning and operating an asset over its entire lifespan.

${ }^{2}$ Net cost-saving is derived from adding the annual avoided operating cost of saved energy due to efficiency gains to the incentives received for pursuing the retrofit, then subtracting the annualized investment cost of the retrofit measure.
} 
where:

$F$ : annualized capital cost of retrofit measures

$O$ : annual operational cost associated with the retrofit measures/equipment

$S$ : annualized incentive on the retrofits

$\Delta E$ : annual energy saved (in coal equivalent) resulting from the retrofits

$P$ : coal price

\section{Key parameters and data sources}

The analysis utilized the information from the cities of Ningbo and Xiee an. In addition to the data availability, there were two other major reasons to select these two cities for the assessment. First, fuel prices are the major contributing factors affecting the economics of industrial boilers. Selecting regions that have different fuel prices can help make effective comparison. Second, the selection of the case study cities was based on the consideration of sufficient supply of major fuels. Ningbo represents port cities with access to coal and liquefied natural gas (LNG) imports while $\mathrm{Xi}{ }^{\mathrm{ee}}$ an represents inland regions with access to the production of coal and natural gas as well as to the interprovincial natural gas pipelines.

The assessment collected data from various sources including: 1) national government policy documents related to the industrial boilers; 2) information provided by the local governments in Ningbo and Xie an, such as boiler inventory data, relevant local policies, as well as city energy supply, consumption, distribution, and price data; 3) information provided by the interviews of industrial experts and facility managers and relevant online databases on boiler products and boiler retrofit measures; 5) boiler performance test reports of local boiler inspection agencies.

Table 1 lists key parameters and assumption used in the techno-economic analysis. A proper discount rate is needed to annualize the investment cost into the future years for a lifetime of a project or technology. A report issued by the Asian Development Bank provides a reference on the choice of an appropriate social discount rate for cost-benefit analysis of public projects or projects related to climate abatement in developing countries [23]. According to the report, social discount rate in China is about $8 \%$ for short and medium term projects and below $8 \%$ for longterm projects. Our interview with an expert at the International Financing Corporation (IFC) indicated that project assessment in China normally uses a discount rate of $12 \%$ for typical investment projects. In a recent World Bank ${ }^{e e}$ assessment of city district heating projects related to boilers in Hebei, China, a discount rate of $10 \%$ was applied ${ }^{3}$. In our study, we used a discount rate of $10 \%$ given that our assessment is more similar to the World Bank case.

Table 1 Key Parameters of Techno-Economic Analysis

\begin{tabular}{|l|c|c|}
\hline \multicolumn{1}{|c|}{ Parameter } & Ningbo & Xi'an \\
\hline Coal price* & $400 \mathrm{RMB}^{4} /$ tonne & $371 \mathrm{RMB} /$ tonne \\
\hline Natural gas price* & $3.04 \mathrm{RMB} / \mathrm{m}^{3}$ & $2.28 \mathrm{RMB} / \mathrm{m}^{3}$ \\
\hline Electricity price* & $0.90 \mathrm{RMB} / \mathrm{kWh}$ & $0.85 \mathrm{RMB} / \mathrm{kWh}$ \\
\hline Heavy oil price* & & $4,250 \mathrm{RMB} /$ tonne \\
\hline
\end{tabular}

\footnotetext{
${ }^{3}$ Personal communication with Zhang Dianjun of International Financing Corporation via correspondence on October 13, 2015.

${ }^{4}$ Ren Min Bi (RMB) is the Chinese currency. $1 \mathrm{RMB}=\$ 0.15$ as of February 6, 2016
} 


\begin{tabular}{|c|c|}
\hline Biomass pellet fuel price* & $1,000 \mathrm{RMB} /$ tonne \\
\hline Discount rate & $10 \%$ \\
\hline Annual steam output of boilers at the size of 10 ton/hour & 30,000 tons of saturated steam at 1.0 megapascal $(\mathrm{MPa})$ \\
\hline Annual steam output of boilers at the size of 20 ton/hour & 50,000 tons of saturated steam at 1.0 megapascal (MPa) \\
\hline Boiler lifetime** & 15 years \\
\hline $\begin{array}{l}\text { Lifetime of distributed combined heat and power** } \\
\text { (CHP) system }\end{array}$ & 25 years \\
\hline Cost of emission regulation compliance*** & $\begin{array}{c}\mathrm{CO}_{2}: 34.94 \mathrm{RMB} / \text { ton, } \mathrm{SO}_{2}: 2.5 \mathrm{RMB} / \mathrm{kg}, \mathrm{NOx}: 5.0 \mathrm{RMB} / \mathrm{kg} \text {, } \\
\text { Flue Dust: } 0.05 \mathrm{RMB} / \mathrm{kg}\end{array}$ \\
\hline \multicolumn{2}{|c|}{$\begin{array}{l}\text { *Coal prices are based on the weighted average coal price of December } 2014 \text { to May } 2015 \text { that considers seasonal price } \\
\text { variation due to the changing demand for coal in different seasons [24]. Natural gas prices are at the city gate. In a } \\
\text { comparison, average U.S. industrial natural price between September } 2014 \text { and February } 2015 \text { was equivalent to } 1.08 \\
\mathrm{RMB} / \mathrm{m}^{3}[25] \text {. Prices for heavy oil and biomass, which have little variation between Ningbo and Xiean, were from the } \\
\text { Chinese experts interviewed by the LBNL team. Electricity prices are based on average electricity rates charged for } \\
\text { industrial customer group of } 1-10 \mathrm{KV}[26,27] \text {. } \\
\text { **Information on the boiler and CHP lifetime is acquired from interviews with the Chinese expert team by the LBNL team. } \\
\text { The number of years is average lifetime of various types of systems. } \\
\text { *** Cost of industrial facilities controlling boiler emissions to comply with government pollution control mandates. } \\
\text { Information on pollutants other than } \mathrm{CO}_{2} \text { based on the interview with Xiean industrial facilities. For } \mathrm{CO}_{2} \text {, the unit cost is the } \\
\text { average value of monthly trading prices of seven local cap-and-trade pilots in China during a one-year period from June } \\
2014 \text { through May } 2015 \text { [28]. }\end{array}$} \\
\hline
\end{tabular}

\section{Results and discussion}

\section{Fuel switching}

The fixed investment and operational costs of industrial boilers with different fuel types are compared using the data from Ningbo and Xie an and shown in Fig.1. The comparison focuses on four types of boilers fueled respectively by natural gas, heavy oil, biomass, and electricity that could potentially replace the coal-fired boilers. Key findings include: 


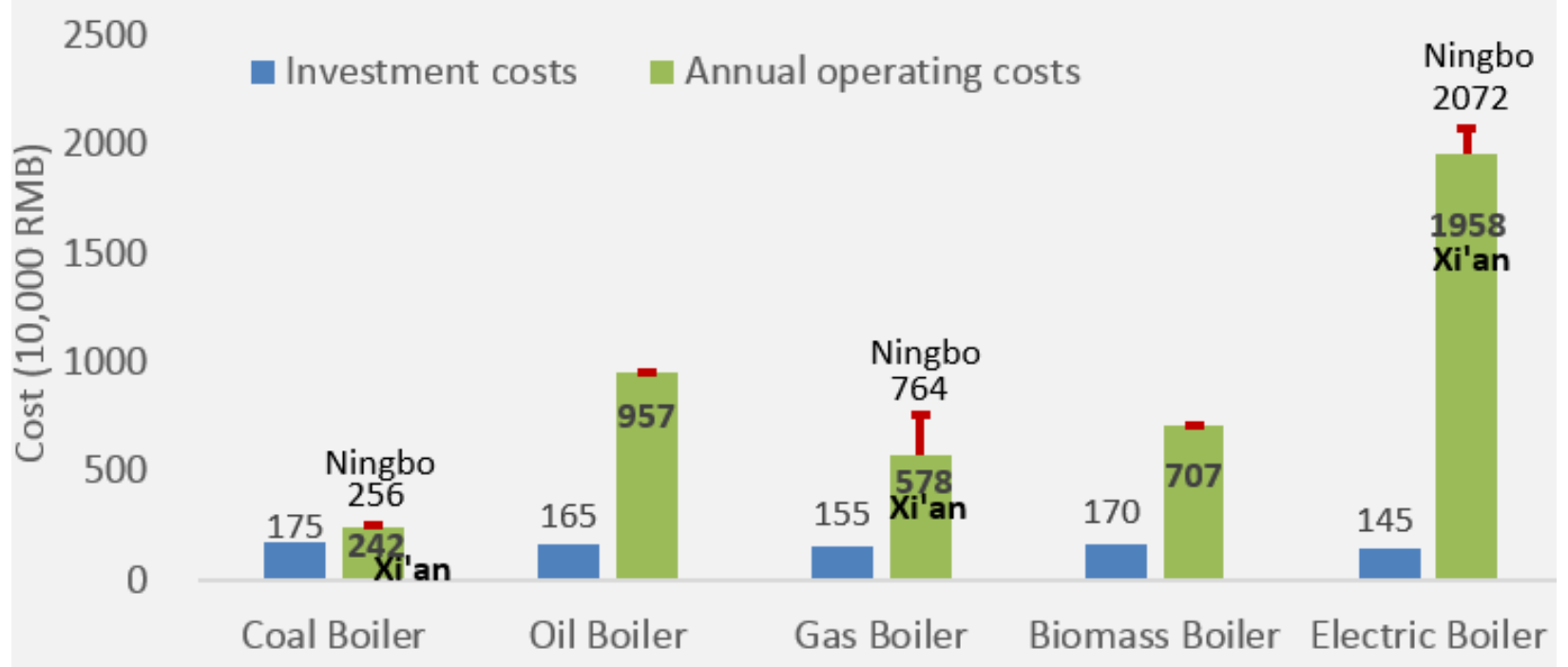

Figure 1. Cost Comparison of Industrial Boilers with Different Fuels

- Among the four fuel-switching options (replacing coal with natural gas, heavy oil, biomass, and electricity, respectively), the fixed costs of investing in different systems do not differ but the operational costs of operating these systems differ significantly due to distinctive fuel prices, which are much higher than the fixed equipment costs. The annual operational cost of coal-fired boilers is significantly lower than that of boilers using alternative fuels.

- Natural gas can be a viable option for fuel switching if the price can be kept competitive. For $\mathrm{Xi}^{\mathrm{e}}$ an, due to its relatively lower natural gas price, the operational cost of natural gas-fired boilers are lower than biomass, heavy oil, and electric boilers. For Ningbo, however, due to its relatively high natural gas price, the operational cost of natural gas-fired boilers is higher than biomass, but lower than oil and electric boilers.

- If simply converting chain-grate stoker boilers to natural gas-fired boilers, the operation costs in Xiee an and Ningbo would increase by $139 \%$ and $198 \%$, respectively. Thus, China ${ }^{e e}$ current high natural gas price is the most dominant barrier to replacing coal with natural gas in small industrial coal-fired boilers.

- Electric boilers are the most costly option mainly due to the energy conversion losses (from thermal energy to electricity, and then from electricity to thermal energy) combined with higher electricity prices for industrial customers in China. Although electric boilers are not an economical option for a complete replacement of coal-fired boilers based on the current higher electricity rates for industrial customers, they can be used as an energy storage option that can supply or store heat during electricity grid off-peak hours when electricity is inexpensive and the increased use of excess power (from sources like wind) is desirable. Using Xiean as an example, for instance, if the electricity tariff went down to below 0.10 
$\mathrm{RMB} / \mathrm{kWh}$ and $0.25 \mathrm{RMB} / \mathrm{kWh}$ respectively, using an electric boiler would be more economical than operating a coal-fired boiler and a natural gas-fueled boiler.

- Biomass could be a good fuel switching option but the Chinese government ${ }^{\text {ee }}$ s current focus on promoting biomass-based electrification can make it hard to bring industrial use of biomass boilers to scale.

\section{Energy efficiency retrofitting}

Energy-saving cost curves of Ningbo and $\mathrm{Xi}^{\mathrm{ee}}$ an are developed to compare the costeffectiveness of various energy efficiency measures for retrofitting existing coal-fired industrial boilers. As shown in Fig.2, five and six of the nine energy efficiency measures that are assessed are cost effective in $\mathrm{Xie}^{\mathrm{e}}$ an and Ningbo, respectively. The assessment shows that the fuel prices play an important role in determining the economic potential of these retrofit measures. Compared the results of the two cities, adopting these measures could create larger cost savings in Ningbo than in $\mathrm{Xi}^{\mathrm{ee}}$ an due to its relatively higher coal prices.

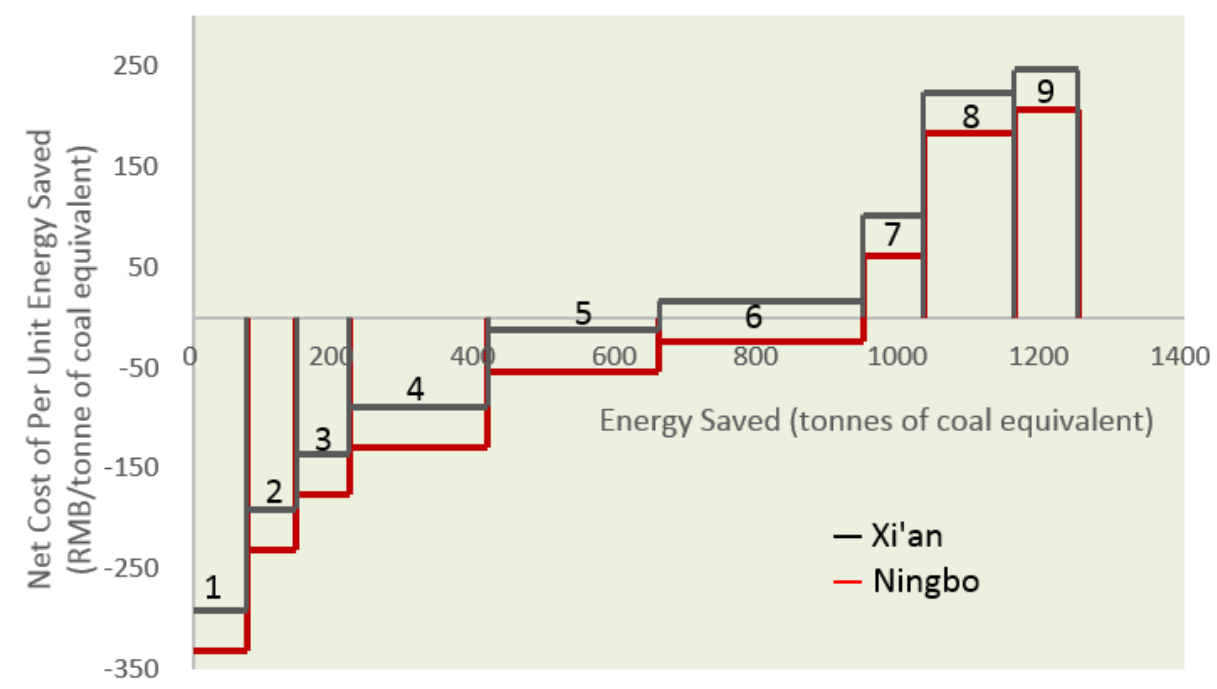

Figure 2. Cost of Energy-Saving Retrofit Measures for Boilers

Notes: Retrofitting measures: 1. excess air management; 2. boiler water treatment anti-corrosion/ scaling energysaving technology; 3. insulation optimization of steam piping, valves, fittings, and vessels; 4 . exhaust gas waste heat recovery; 5 . condensate recovery; 6 . compound combustion technology for chain-grate boilers; 7 . boiler blowdown treatment and heat recovery; 8 . boiler intelligent soot blowing optimization and online coking warming system; 9. flash steam recovery.

\section{Community-scale system}

This option assessed the cost-effectiveness of replacing scattered boilers with a community-scale, distributed boiler service station. For this assessment, we analyzed the case of removing a number of small natural gas boilers in five industrial facilities located within a 10-kilometer diameter ${ }^{5}$ in $\mathrm{Xi}^{\mathrm{e}}$ an and replacing them with a larger system that can serve the aggregate steam and heat loads of these facilities. In our assessment, the costs of three types of community-scale systems (i.e., a natural gas-based CHP, a large coal-fired boiler, and a large natural gas boiler)

\footnotetext{
${ }^{5}$ Serving loads within an effective geographical range is desirable for a community-scale system so that heat losses from delivering steam/heat from the system to loads can be minimized.
} 
were compared with that of dispersed natural gas boilers traditionally operated by facilities themselves. The comparison also assessed the scenarios that reflect the added cost of facilities meeting environmental obligations and the reduced cost due to natural gas price reduction. Cost comparison results are summarized in Table 2. Several conclusions can be drawn:

- Although the three types of community-scale system differ in cost, all of them are more economical than five facilities operating their own boilers. This indicates that replacing selfoperated boilers with a community-scale system can be a cost-effective solution.

- A coal-fired community-scale system seems to be the most economical option among all the

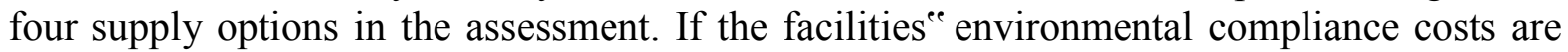
not considered, the cost ratios of the community-scale coal-fired boilers, the communityscale natural gas boilers, the natural gas-based CHP, and facilities operating their own small natural gas boilers are: $1: 2.62: 2.73: 2.94$. After adding the environmental compliance costs, however, the cost ratios change to $1: 2.00: 2.12: 2.24$, indicating that the cost advantage of the coal-fired community-scale boilers decreases when environmental compliance cost of burning coal is taken into account. More stringent regulations on air pollution and greenhouse gas emissions could significantly increase the cost of using coal.

- Among all types of community-scale systems assessed in the analysis, the natural gas-based CHP system that is equipped with micro-turbines has the highest cost, but is still less expensive than the combined cost of five facilities operating their own boilers. The high cost of the distributed CHP system is due to the high equipment cost of micro-turbines, which are the main component of the distributed CHP systems but currently have a very limited use in China. With the scale-up of the CHP equipment market, the gradual decline of natural gas prices, and stronger policy support for promoting natural gas-based distributed energy in China, the economic benefits of natural gas-based CHP systems will be further improved. A further reduction of natural gas prices (e.g., a reduction of $0.50 \mathrm{RMB} / \mathrm{m}^{3}$ from the current level) can make the CHP system more economical than a community-scale natural gas system and change the cost ratios of community-scale coal-fired boilers, natural gas-based CHP, community-scale natural gas boilers, and facilities operating their own natural gas boilers to: $1: 1.43: 1.61: 1.84$.

Table 2 Comparison of Community-Scale Systems vs. Scattered Units, Xieean

\begin{tabular}{|c|c|c|c|c|c|}
\hline \multirow[b]{2}{*}{ Category } & \multirow[b]{2}{*}{ Indicators } & $\begin{array}{l}\text { 1. Natural gas- } \\
\text { based CHP }\end{array}$ & \multirow{2}{*}{$\begin{array}{l}\text { 2. Community- } \\
\text { scale coal-fired } \\
\text { boilers }\end{array}$} & \multirow{2}{*}{$\begin{array}{l}\text { 3. Community } \\
\text {-scale natural } \\
\text { gas boilers }\end{array}$} & \multirow{2}{*}{$\begin{array}{l}\text { 4. Scattered } \\
\text { natural gas } \\
\text { boilers } \\
\text { operated by } \\
\text { individual } \\
\text { facilities }\end{array}$} \\
\hline & & $\begin{array}{c}\text { Thermal to } \\
\text { electricity ratio: } \\
3.5: 1\end{array}$ & & & \\
\hline Equipment & $\begin{array}{l}\text { Equipment cost } \\
\text { (10,000 RMB) }\end{array}$ & 14000 & 2400 & 2100 & 3600 \\
\hline Fuel & $\begin{array}{l}\text { Annual consumption of } \\
\text { coal (tonnes) or natural } \\
\text { gas }\left(10,000 \mathrm{~m}^{3}\right)\end{array}$ & 47664.12 & 48129.4 & 26914.8 & 27526.48 \\
\hline \multirow{2}{*}{$\begin{array}{l}\text { Cost (exclude the } \\
\text { environmental } \\
\text { compliance cost) }\end{array}$} & $\begin{array}{c}\text { Net cost* } \\
(10,000 \mathrm{RMB})\end{array}$ & 6976.78 & 2552.64 & 6697.66 & 7515.51 \\
\hline & $\%$ of the cost of option 4 & $92.8 \%$ & $33.96 \%$ & $89.12 \%$ & $100 \%$ \\
\hline
\end{tabular}




\begin{tabular}{|c|c|c|c|c|c|}
\hline $\begin{array}{c}\text { Cost (include } \\
\text { environmental } \\
\text { compliance cost) }\end{array}$ & $\begin{array}{c}\text { Net cost* } \\
(10,000 \mathrm{RMB})\end{array}$ & 7293.74 & 3435.33 & 6876.65 & 7698.56 \\
\cline { 2 - 6 } & $\%$ of the cost of option 4 & $94.74 \%$ & $44.62 \%$ & $89.32 \%$ & $100 \%$ \\
\hline $\begin{array}{c}\text { Cost (with } \\
\text { environmental } \\
\text { compliance cost } \\
\text { and a further } \\
\text { reduction of } \\
\text { natural gas price } \\
\left.\text { by } 0.50 \mathrm{RMB} / \mathrm{m}^{3}\right)\end{array}$ & $\begin{array}{c}\text { Net cost* } \\
(10,000 \mathrm{RMB})\end{array}$ & 4910.54 & 3435.33 & 5530.91 & 6322.23 \\
\cline { 2 - 6 } & $\%$ of the cost of option 4 & $77.67 \%$ & $54.34 \%$ & $87.48 \%$ & $100 \%$ \\
\hline
\end{tabular}

\section{Barriers to Adopting Cost-Effective Solutions to Industrial Boilers}

The techno-economic analysis has shown that retrofitting existing coal-fired boilers, fuel switching from coal to natural gas, and efficient use of resources via a community-scale distributed CHP system can be effective alternatives to industrial coal-fired boilers. However, China faces many barriers that can prevent these opportunities from being fully captured. Table 3 summarizes these barriers.

Table 3 Barriers to Adoption of Cost-Effective Solutions for Industrial Boilers

\begin{tabular}{|c|c|c|}
\hline & & (DE) and CHP \\
\hline $\begin{array}{l}\text { proper efficiency } \\
\text { s for pulverized } \\
\text { ers, small electric } \\
\text { and biomass boilers } \\
\text { performance } \\
\text { s for the steam } \\
\text { standardized boiler } \\
\text { a procedures } \\
\text { nologies } \\
\text { arket share for high } \\
\text { technologies such } \\
\text { zed bed boilers } \\
\text { esign focusing } \\
\text { safety and less on } \\
\text { erformance } \\
\text { ss on steam } \\
\text { vide improvements } \\
\text { matiligent systems } \\
\text { ag optimal boiler }\end{array}$ & $\begin{array}{l}\mathrm{g} \\
\text { ategies, } \\
\text { hnical } \\
\text { p after } \\
\text { on of } \\
\text { sulting in } \\
\text { deploy } \\
\text { ions } \\
\text { lack of } \\
\text { cale } \\
\text { roval of } \\
\text { projects } \\
\text { or } \\
\text { al gas }\end{array}$ & $\begin{array}{l}\text { atory and administrative } \\
\text { s } \\
\text { ck of access to the } \\
\text { ectrical grid and thermal } \\
\text { stribution network, } \\
\text { sulting in operations in } \\
\text { sland Mode," preventing } \\
\text { HP and DE from } \\
\text { aximizing their potential } \\
\text { urdensome permitting } \\
\text { olongs the process to } \\
\text { velop CHP and DE } \\
\text { ck of comprehensive plans } \\
\text { ads to highly fragmented } \\
\text { HP operations, creating } \\
\text { aproper economies of scale } \\
\text { tional barriers } \\
\text { ack of coordination between } \\
\text { at supply and heat } \\
\text { stribution systems which } \\
\text { e managed by different } \\
\text { irties } \\
\text { t and financial barriers } \\
\text { tilities view distributed } \\
\text { HP and DE as potential }\end{array}$ \\
\hline
\end{tabular}




\begin{tabular}{|c|c|c|}
\hline $\begin{array}{l}\text { sub-optimal boiler } \\
\text { performance } \\
\text { - } \text { Lack of standardized } \\
\text { operation practices, leading } \\
\text { to low efficiency } \\
\text { - } \text { Use of low-end, inefficient } \\
\text { natural gas or biomass } \\
\text { boilers due to higher fuel } \\
\text { prices } \\
\text { Lack of capacity } \\
\text { - Low education levels and } \\
\text { lack proper training for } \\
\text { boiler operators } \\
\text { - Lack of resource guides, } \\
\text { best practices, and toolkits } \\
\text { about energy efficiency } \\
\text { opportunities and } \\
\text { management practices } \\
\text { Lack of monitoring and } \\
\text { enforcement } \\
\text { Lack of tracking and } \\
\text { reporting of boiler energy } \\
\text { and environmental } \\
\text { performance } \\
\text { Lack of strong measures to } \\
\text { enforce established boiler } \\
\text { efficiency standards }\end{array}$ & $\begin{array}{l}\text { developing LNG projects and } \\
\text { the price volatility of LNG } \\
\text { and natural gas } \\
\text { - Uncertainty about } \\
\text { government strategy on } \\
\text { biomass increases hesitation } \\
\text { of private companies to invest } \\
\text { in biomass boilers } \\
\text { - Production of biomass } \\
\text { materials dominated by small } \\
\text { firms that cannot survive } \\
\text { without government subsidy } \\
\text { Shortage of gas supply and high } \\
\text { gas prices } \\
\text { - Shortage of gas supply for } \\
\text { industrial use due to } \\
\text { prioritization of residential } \\
\text { and public sector gas use } \\
\text { Higher industrial gas prices } \\
\text { due to the growing gaps } \\
\text { between demand and supply } \\
\text { and the subsidized prices for } \\
\text { residential and public gas use } \\
\text { End-users lack effective } \\
\text { financial instruments and risk } \\
\text { management strategies to } \\
\text { hedge against fuel price } \\
\text { volatility }\end{array}$ & $\begin{array}{l}\text { their sales } \\
\text { Actual costs for producing } \\
\text { and distributing power and } \\
\text { heat from CHP are not } \\
\text { always reflected in the tariffs, } \\
\text { making investment in CHP } \\
\text { less attractive } \\
\text { - Lack of motivation for end- } \\
\text { users to save energy and for } \\
\text { investors to invest in CHP } \\
\text { due to the fact that heat } \\
\text { services in residential and } \\
\text { public sector often at a flat } \\
\text { rate } \\
\text { First-cost hurdle and lack of } \\
\text { access to finance hinder the } \\
\text { expansion of CHP and DE } \\
\text { Lack of tax and fiscal } \\
\text { incentives and other } \\
\text { stimulating measures to spur } \\
\text { investment in CHP and DE } \\
\text { Technical barriers } \\
\text { - Lack of experience and tools } \\
\text { for designing optimal system } \\
\text { configurations } \\
\text { Distributed CHP lacks } \\
\text { modular design to have a } \\
\text { flexible capacity }\end{array}$ \\
\hline
\end{tabular}

Sources: [29], [30], [31], [32], [33]

\section{Recommendations of Removing Barriers to Achieving Potential for Industrial Boilers}

It is in the China ${ }^{e e}$ s best interest in adopting effective strategies to remove the barriers to realizing cost-effective opportunities. We recommend that the governments in China, both at central and local, take the following specific actions.

Developing comprehensive post-elimination strategies: China can take the full advantage of eliminating small boilers to develop comprehensive post-elimination strategies. Without effective strategies, opportunities to take broader actions could be missed. Therefore, it is important for city governments in China to provide the necessary resources to support industrial facilities in developing and deploying comprehensive and cost-effective strategies. It is also important for cities to leverage the opportunity to undertake appropriate plans that will accelerate and coordinate efficiency improvement, fuel switching, and the adoption of CHP and distributed energy.

Creating enabling policies: pursuing comprehensive strategies requires policy changes on several fronts. First, China can increase market competition and reduce "soft costs" by adopting facilitation policies and reducing administrative hurdles to encourage the market entrance of 
private service providers and third-party suppliers. Second, city governments can effectively engage the private sector through public-private partnerships in building gas supply infrastructure and expanding the heat distribution networks. Third, continuing reforms on gas pricing are needed to reduce disparities in prices between the industrial sector and other sectors (e.g., residential) and to reduce the windfall profit of monopolized gas companies. In addition, to attract private investments, China could establish a "feed-in" tariff for CHP and distributed energy projects to reduce costs, encourage technology advancement, and provide market certainty that help attract finance for these projects. Finally, China could consider improving policies to facilitate the increased access of private businesses or industrial CHP and distributed energy systems to state-owned gas distribution systems, LNG receiving terminals, local electric grids, and cities ${ }^{\text {ee }}$ thermal distribution networks.

Accelerate technology development and deployment: China will continue to use coal as a main energy resource in the foreseeable future and has plans to use coal in a cleaner and more efficient manner. Nonetheless, it is also important for the country to make strategic efforts in the research and development and market deployment of alternative solutions to avoid creating an energy infrastructure that will be dependent on coal in the long run. Government tax and financial incentives could help accelerate the development and deployment of alternative energy solutions such as boiler system optimization, low carbon fuels (e.g., natural gas, shale gas, biomass, and solar thermal), and integrated applications such as waste-to-energy, CHP and distributed energy.

Strengthening standardization: It is important for China to formulate effective energy efficiency standards and associated testing protocols that set proper energy performance requirements for industrial boilers burning coal or alternative fuels. China also needs to develop effective standards or consistent procedures governing boiler-related coal processing, operations, tune-up, and water treatment as well as specifications that set goals for boiler and ancillary parts performance at the system level. To ensure the optimal performance of boilers, policies need to consider setting necessary requirements for boiler design, manufacturing, and operations. In addition, the development of standards regulating the performance of CHP and distributed energy is essential to the widespread adoption of these applications. Finally, it is important for China to formulate rules and standards for interconnecting CHP and distributed resources with power and heat networks.

Developing innovative business models and financing mechanisms: Innovations in business models and financing are essential to stimulating private investments in advanced technologies and integrated solutions. China can consider different models. For example, the traditional business models of boiler manufacturers can be changed such that instead of supplying equipment, these manufacturers can supply steam or heat services. Another financing model that may be considered is one that is similar to the Power Purchase Agreements. This model would require the development of a service scheme with fee payment or a long-term service purchase agreement. China can also encourage the formation of public-private partnership in which the administrator of a local industrial park can aggregate the needs of its industrial customers and solicits bids for heat/steam/electricity services.

Strengthening regulatory enforcement: It is essential for China to enhance its capacity in monitoring, reporting, and verifying regulation compliance regarding industrial boilers. Establishing a national database through one centralized point of access (like the Compliance and Emissions Data Reporting Interface or CEDRI ${ }^{6}$ of the U.S. Environmental Protection

\footnotetext{
${ }^{6}$ Information about CEDRI can be found at http://epa.gov/ttn/chief/cedri/index.html
} 
Agency) can be an effective way to reporting of regulation compliance. To increase the effectiveness of China "es enforcement efforts, it is also important for the country to improve the flexibility of the enforcement. For example, China could consider learning the experience of the U.S. Environmental Protection Agency Boiler MACT regulation which allows industrial facility owners to receive compliance credits to offset emissions with energy efficiency improvement in their facilities [34]. China could also create customized requirements on tune-up schedules that fit facilities ${ }^{\text {ec }}$ operation conditions. It would be best if China avoids one-size-fits-all types of enforcement policies and allows for greater flexibility so that industrial facilities can find the most cost-effective way to achieve regulation targets while still being in compliance with government requirements.

Enhance technical support and build strong capacity: It is important for China to develop effective technical assistance programs to assist in the implementation of strategies recommended. The technical assistance should provide assessment tools, trainings, technical guides, and case studies. Further, building a strong capacity is a critical step in gaining buy-in from stakeholders on the need for solutions and in helping stakeholders understand the solutions. It is important for China to develop effective capacity building programs that cover a wide range of topics from regulations and standards to retrofit technologies, fuel switching, renewable energy, boiler operations and maintenance as well as project contracting and finance. In addition, to ensure effective regulations enforcement, government-funded training activities are needed to provide examiners, inspectors, and verifiers with the knowledge and skills needed to do their jobs.

\section{Conclusion}

China's industrial boilers are major energy consuming equipment and one of the key sources of greenhouse gas emissions and local pollution in China. Elimination of small coal-fired boilers and promoting fuel switch to replace coal are actions taken by the Chinese government to address industrial coal-fired boilers. Significant policy, market, and technology barriers are present in China preventing the wide adoption of feasible options analyzed in this paper including switching coal to other fuels such as natural gas, retrofitting existing boiler systems with energy efficiency improvement measures, and developing distributed energy and CHP applications to replace scattered boilers. It is in the China ses best interest to make serious efforts to remove the barriers and to take the full advantage of eliminating small boilers to carry out appropriate plans that will accelerate and coordinate efficiency improvement, fuel switching, and the adoption of CHP and distributed energy.

\section{Acknowledgements}

The work presented is a result of the research project supported by the U.S. Department of State under U.S. Department of Energy Contract No. DE-AC02-05CH11231 with the Regents of the University of California. Moreover, we wish to thank Sandra Oudkirk, Julie Kim, and David Vance Wagner of the U.S. State Department and Dr. Jiang Jinghao of China es National Development and Reform Commission for their insights. The authors would also like to thank the Chinese expert team members including Wei Xiangyang, Zhang Yunpeng, Guan Jian, Hou Rui, Zhang Junfeng, Zhuo Yuqun, and Xia Shumao for providing technical guidance during this project and Angela Liu and Katherine Tsen for their assistance in the study. In addition, the authors would like to express their thanks to special equipment inspection and testing institutes in $\mathrm{Xie}^{\mathrm{ee}}$ an and Ningbo for providing information on their cities ${ }^{e c}$ boiler operation characteristics. 


\section{References}

[1] Ministry of Industry and Information Technology (MIIT). 2014. "Seven governmental agencies jointly releasing the Comprehensive Implementation Plan of Improving Coal-Fired Boiler Energy-Saving and Environmental Protection Performance", October 29. [Chinese text]. http:/www.miit.gov.cn/n1146290/n4388791/c4216991/content.html (accessed on September 19, 2016)

[2] Energy Research Institute of China (ERI). 2013. Roadmap Study on Achieving Technical Energy Conservation Potential in China's Industrial Sector by 2020, Beijing: China Scientific Technology Press.

[3] Gao JJ. 2013. "Research on China High Energy Consuming Equipment Operation Status and Energy Saving Solutions", the final report of the Research Project on China High Energy Consuming Equipment Operation Status and Energy Saving Solutions commissioned by the Chinese Academy of Engineering. Beijing, China: China Science Press. March 2013.

[4] Dechert S. 2015. "China Coal Consumption \& $\mathrm{CO}_{2}$ Emissions Drop In 2014.” http://cleantechnica.com/2015/03/13/china-coal-consumption-co2-emissions-drop-2014/ (accessed on September 19, 2016)

[5] Du KJ. 2012. "The Improvement and Application of Pulverized Coal Compound Combustion Technology in Chain-grate Stoker Industrial Boiler.” Industrial Boiler Magazine. 2012(6)

[6] United Nations Industrial Development Organization (UNIDO). 2014. Energy Efficiency Potentials in Industrial Steam Systems in China: Development of a steam systems energy efficiency cost curve. Vienna, 2014.

http:/www.unido.org/fileadmin/user media upgrade/What we do/Topics/Energy access/EE P otentials_Steam_Systems_China_.pdf (accessed on September 19, 2016)

[7] Song, WC.1999. "Development strategy of natural gas for 21 century in China." Natural Gas Industry; 19 (4): 23-27.

[8] Mao XQ, Guo XR, Chang YG, Peng YD. 2005. "Improving air quality in large cities by substituting natural gas for coal in China: Changing idea and incentive policy implications." Energy Policy; 33: 307.

[9] Coria J. 2009. "Environmental policy, fuel prices and the switching to natural gas in Santiago, Chile.” Ecological Economics; 68: 2877.

[10] Fang JH, Li GH, Aunan K, Vennemo H, Seip HM, Oye KA, Beer JM. 2002. “A proposed industrial-boiler efficiency program in Shanxi: Potential $\mathrm{CO}_{2}$-mitigation, health benefits and associated costs." Applied Energy; 71(4): 275-285.

[11] Aunan K, Fang JH, Vennemo H, Oye K, Seip HM. 2004. "Co-benefits of climate policylessons learned from a study in Shanxi, China.” Energy Policy; 32 (4): 567-581.

[12] Sims R, Rogner HH, Gregory K. 2003. "Carbon emission and mitigation cost comparisons between fossil fuel, nuclear and renewable energy resources for electricity generation." Energy Policy; 31(13): 1315-1326. 
[13] Demirbas A. 2005. "Potential applications of renewable energy sources, biomass combustion problems in boiler power systems and combustion related environmental issues." Progress in Energy and Combustion Science; 31(2): 171-192.

[14] Zhang YM, Mckechnie J, Cormier D, Lyng R, Mabee W, Ogino A, and Maclean HL. 2010. "Life cycle emissions and cost of producing electricity from coal, natural gas, and wood pellets in Ontario, Canada." Environmental Science and Technology; 44: 538.

[15] Saidur R, Abdelaziz EA, Demirbas A, Hossain MS, and Mekhilef S. 2011. "A review on biomass as a fuel for boilers." Renewable and Sustainable Energy Reviews; 15(5): 2262-2289.

[16] Li, Jun, Weihong Yang, Wlodzimierz Blasiak, and Anna Ponzio. 2012. "Volumetric combustion of biomass for $\mathrm{CO}_{2}$ and NOx reduction in coal-fired boilers." Fuel: 624.

[17] Laursen, K., and J. R. Grace. 2002. "Some implications of co-combustion of biomass and coal in a fluidized bed boiler." Fuel Processing Technology 76: 77.

[18] Li, Jun, Artur Brzdekiewicz, Weihong Yang, and Wlodzimierz Blasiak. 2012. "Co-firing based on biomass torrefaction in a pulverized coal boiler with aim of $100 \%$ fuel switching." Applied Energy 99: 344.

[19] Yang, Ming, and Robert K. Dixon. 2012. "Investing in efficient industrial boiler systems in China and Vietnam.” Energy Policy 40: 432.

[20] He, K., Y. Lei, X. Pan, Y. Zhang, Q. Zhang, and D. Chen. 2010. "Co-benefits from energy policies in China." Energy 35: 4265.

[21] Xiong, W., Y. Wang, B.Vad Mathiesen, H. Lund, and X. Zhang. 2015. "Heat roadmap China: New heat strategy to reduce energy consumption towards 2030". Energy 81: 274-285. http://dx.doi.org/10.1016/j.energy.2014.12.039

[22] Liu, W., H. Lund, and B. Vad Mathiesen. 2011. "Large-scale integration of wind power into the existing Chinese energy system”, Energy 36: 4753-4760. doi:10.1016/j.energy.2011.05.007

[23] Zhuang JZ, Liang ZH, Lin T, Guzman FD. 2007. Theory and Practice in the Choice of Social Discount Rate for Cost-Benefit Analysis: A Survey. Economics and Research Department Working Paper Series No. 94. Manila, Philippine: Asian Development Bank.

https://www.adb.org/sites/default/files/publication/28360/wp094.pdf (accessed on September 25, 2016)

[24] China Coal Market Portal. http://www.cctd.com.cn/list-167-1.html (accessed September 25, 2016)

[25] U.S. Energy Information Administration (U.S. EIA), 2015. Natural Gas Prices. http://www.eia.gov/dnav/ng/ng_pri_sum_dcu_nus_m.htm (accessed on September 25, 2016)

[26] Ningbo Development \& Reform Commission (NBDRC).

http://www.nbdpc.gov.cn/SiteModules/ExpandMan/GuestBook/View.aspx?GBId=2171\&num

(accessed on September 25, 2016)

[27] Shan 'xi Provincial Pricing Bureau (SPPB). Announcement on Adjusting Shan xi Grid Tariff. http://www.spic.gov.cn/default.asp (accessed on September 25, 2016)

[28] Carbon Trading Portal. http://tanpaifang.com/ (accessed on September 25, 2016) 
[29] China Energy Newspaper. Urban Combined Heat and Power Systems Face Three Main Obstacles, December 10, 2012. http://paper.people.com.cn/zgnyb/html/2012-

12/10/content_1156995.htm (accessed on September 25, 2016)

[30] China Energy Newspaper. Heat and Power Sector Welcomes Favorable Governmental Policies, July 8, 2013. http://paper.people.com.cn/zgnyb/html/2013-07/08/content_1266150.htm (accessed on September 25, 2016)

[31] China LNG \& Gas International Summit \& Exhibition. Focus: Private Companies Enter LNG Market in China", April 17, 2015.

http://www.chinalng.cc/hangyexinwen/2015/0417/598.html (accessed on September 25, 2016)

[32] Ministry of Environmental Protection (MEP). Soliciting Public Feedback on „Emission standard of air pollutants for boilers", August 2, 2013.

http://www.zhb.gov.cn/gkml/hbb/bgth/201308/t20130805 256939.htm (accessed on September 25, 2016)

[33] Sina News. First Private-Owned LNG Station in Construction: will be difficult for ENG to break the oil \& gas market monopoly, August 17, 2013. http://finance.sina.com.cn/chanjing/gsnews/20130817/100616479941.shtml (accessed on September 25, 2016)

[34] Shen B., Lu HY, Price L. 2015. U.S. Experiences in Tackling Energy and Environmental Challenges of Boiler System, LBNL-1004067. Berkeley, CA: Lawrence Berkeley National Laboratory 